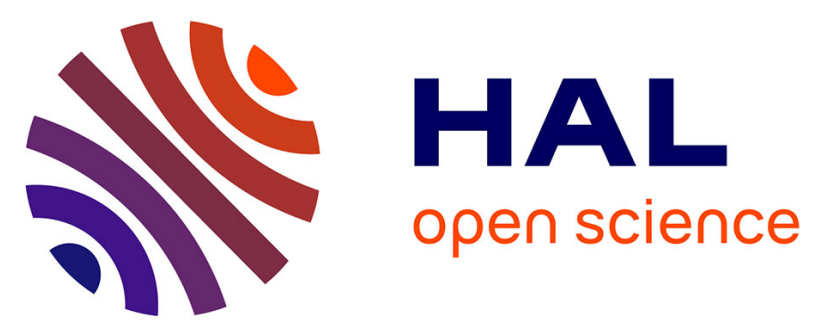

\title{
Relevance of macrozoobenthic grazers to understand the dynamic behavior of sediment erodibility and microphytobenthos resuspension in sunny summer conditions
}

Francis Orvain, Katell Guizien, Sébastien Lefebvre, Martine Bréret, Christine Dupuy

\section{To cite this version:}

Francis Orvain, Katell Guizien, Sébastien Lefebvre, Martine Bréret, Christine Dupuy. Relevance of macrozoobenthic grazers to understand the dynamic behavior of sediment erodibility and microphytobenthos resuspension in sunny summer conditions. Journal of Sea Research (JSR), 2014, 10.1016/j.seares.2014.03.004 . hal-01248060

\section{HAL Id: hal-01248060 \\ https://hal.science/hal-01248060}

Submitted on 26 Dec 2016

HAL is a multi-disciplinary open access archive for the deposit and dissemination of scientific research documents, whether they are published or not. The documents may come from teaching and research institutions in France or abroad, or from public or private research centers.
L'archive ouverte pluridisciplinaire HAL, est destinée au dépôt et à la diffusion de documents scientifiques de niveau recherche, publiés ou non, émanant des établissements d'enseignement et de recherche français ou étrangers, des laboratoires publics ou privés. 
Relevance of macrozoobenthic grazers to understand the dynamic behavior of sediment erodibility and microphytobenthos resuspension in sunny summer conditions

Orvain Francis $^{1}{ }^{*}$, Guizien Katell ${ }^{2}$, Lefebvre Sébastien ${ }^{3}$, Bréret Martine ${ }^{4}$, Dupuy Christine ${ }^{5}$

1 : Université de Caen Basse-Normandie, UMR BOREA (MNHN, UPMC, UCBN, CNRS7208, IRD-207), esplanade de la Paix, 14032 Caen, France.

2 : CNRS-Université Pierre et Marie Curie, UMR 8222 Laboratoire d'Ecogéochimie des Environnements Benthiques, Observatoire Océanologique de Banyuls-sur-Mer, UMR8222, rue du Fontaulé, 66650 Banyuls-sur-Mer, France

${ }^{3}$ : UMR 8187 CNRS LOG "Laboratoire d'Océanographie et de Géoscience", Université de Lille1, Station Marine de Wimereux, 28 avenue Foch, 62930 Wimereux, France.

${ }^{4}$ : UMR 7266 CNRS - Laboratoire LIENSs, Université de La Rochelle, 2 rue Olympe de Gouges, 17000 La Rochelle cedex, France.

* Corresponding author: francis.orvain@unicaen.fr 


\section{Abstract}

The quantification of overall microphytobenthos productivity should include the export of biomass from the intertidal zone during high tides, which implies refined estimates and concepts of erosion parameters. For the first time, the export of microphytobenthic cells was assessed over an intertidal mudflat in the Marennes-Oléron bay, France, during a complete spring/neap tide modulation of 13 days in the summer of 2008. Resuspension rates of chl- $a$ exported only reached $2.5 \%$ of the standing stock of benthic diatoms on each day. Sedimentary factors failed to explain any variation regarding bed and microphytobenthos erodibility. During the early fluff layer erosion phase, there were negative effects of grazing activities exerted by motile infauna (Peringia ulvae) on erosion fluxes of chl $a$, while there was a related positive correlation with pheopigment proportion. The erosion process plays an important role in this vegetal-herbivore interaction by reinforcing the decline of the microphytobenthic biomass and provoking a catastrophic shift to mass erosion after a sequence of several days of co-occurring intense grazing by snails and chl- $a$ decline. During mass erosion, the biofilm decline explained the variations of sediment erodibility, with a marked negative correlation between bound extracellular polymeric substance (EPS) proteins and critical threshold for bed erosion, in contrast with the commonly observed positive influence of EPS secretion on bed resistance. The complex nature of the effects of EPS by microphytobenthos must be further investigated to unravel their complex role in bioengineering sediments. The increase of protein proportion in EPS could provide specific properties related to hydrophilic features. Nevertheless, the level of grazing pressure by Peringia ulvae should be so intense that the top-down control must explain this original finding, since there was a positive correlation of proteins in EPS and snail density that could be related to mucus secretion (as a constitutive part of the EPS pool). 
Key words: Erosion, grazing, benthic diatoms, biofilm, intertidal mudflat, extracellular polymeric substances, Protein, Top-down control 


\section{Introduction}

In intertidal soft-sediment habitats, the microorganisms developing at the sedimentwater interface form a consortium within a microphytobenthos (MPB) biofilm that is generally controlled by the physical environment. However, this biota also mediates physical processes as bioengineers (see Orvain et al., 2014 for details about potential interactions between microorganisms making the consortium). All microorganisms living upon bare intertidal mudflats can enter the pelagic food web, and can serve as food items for zooplankton and benthic suspension-feeders (Herman et al., 2000). Given the value of ecological processes in estuarine ecosystems and the level of human disturbance in these areas (shellfish exploitation, fisheries, littoral modification, watershed water discharge, accumulation of pollutants, eutrophication, etc), it is of primary importance to understand the natural processes that govern their dynamics, and especially microphytobenthos resuspension. It remains an important challenge to quantify and model the complex dynamics and fates of matter and energy fluxes between sediment habitats and the water column, and to provide models predicting the overall functioning of intertidal ecosystems.

Benthic diatom resuspension into the water column is directly related to hydrosedimentary dynamics, which is affected by Bed Shear Stress (BSS) itself, depending on the intensity of tidal currents and wind-induced waves. The erosion fluxes depend also on sediment erodibility, which is defined as the resistance of the sediment to erosion, a highly variable parameter in space and time (Tolhurst et al., 2003). The changes in bed erodibility result from complex interrelationships between sediment properties, bioturbation activities by macrofauna, and microphytobenthic biofilms especially in summer (Herman et al., 2001; Orvain et al., 2004; Thrush et al., 2012; Wood and Widdows, 2002); but also events like direct rainfall, especially in winter (Pilditch et al., 2008; Tolhurst et al., 2008b). In more detail, the MPB could play a role as a sediment stabiliser, either by secreting EPS (ExoPolymeric Substances), via binding properties, or by forming an armouring biofilm over the sediment surface (Tolhurst et al., 2003) in close association to the 3D-microstructural assemblage of microorganisms within the biofilm (de Brouwer et al., 2005). When biofilms are saturated with benthic diatoms, destabilising factors can also be imputed to some EPS fraction when they reinforce water retention of sediments by acting like sponges, or when they promote bacteria degradation of the biofilm, and disruption of the biofilm (Orvain et al., 2003; Yallop et al., 2000). The latter phenomenon probably remains rare in the field, but is easily induced in lab controlled conditions when processes responsible for MPB removal like resuspension and grazing by macrofauna are removed and biofilm thickness is increased (Tolhurst et al., 2008a).

There are many processes that could explain the nature of biostabilisation, but many still require further investigation, such as the effects of tidal variation along a spring/neap tidal cycle, which have not previously been described in literature. Simple projection on the observation of the short-term dynamics of MPB biomasses (Blanchard et al., 2002) suggested that resuspension of benthic diatoms should be important in the Marennes-Oléron bay when shifting from spring tides to neap tides during the early spring or in summer, i.e. when microphytobenthos blooms develop, and when phytoplankton biomass remains low (Guarini et al. 2008; Blanchard et al., 2002). EPS-induced bioengineering of sediments must therefore be exacerbated in these conditions. The temporal patterns of MPB development and resuspension vary extremely depending on the spring/neap tidal cycle phase, seasonal patterns, and meteorological events (Orvain et al., 2012). The variability in light exposure and temperature at various temporal scales (hour - day - month - year) interrelate with an already complex network of interactions, so that MPB via sediment biostabilisation can be considered to be an ecosystem engineer resulting in idiosyncratic responses of the ecosystem's functions 
(Tolhurst et al., 2003) due to several feedback mechanisms (Weerman et al., 2011). There is still a necessity to unravel the drivers of MPB and sediment erodibility, to be able to predict their erosion in natural settings where hydrodynamic drivers are now being predicted with improving accuracy.

The main objectives of the present study were to understand the sediment and biofilm parameters most able to control bed and microphytobenthos erodibility, and to quantify how these were affected by the tidal cycle. In addition, it was intended to assess whether the microphytobenthic resuspension net export could be predictable as a function of tidal and light conditions. To enhance the ability to detect effects of tidal regime, the experiment was conducted during 13 subsequent days, during high and low degrees of light exposure (see Table 1). If MPB and associated EPS alone were the most important factor in driving sediment erodibility, a consistent response to tidal effects would be expected to be seen (i.e. bottom-up effects). If grazing by macrofauna was the most important, strong dependence upon snail abundance and/or pheopigment, in addition to a lack of tidal influence, would be expect to be seen (i.e. top-down effects). In the present study, sediment and MPB erodibility parameters (critical BSS for erosion and erosion rates) were measured at the end of each diurnal low-tide of a 13-day period. These erodibility descriptors were compared to an exhaustive set of biofilm properties: MPB (chl- $a$ concentration in the $1^{\text {st }} \mathrm{mm}$, and the $1^{\text {st }} \mathrm{cm}$, EPS carbohydrates, and proteins), bacteria, macrofauna, and sediment parameters. Recent studies on sediment erodibility used miniaturised techniques measuring critical threshold for erosion like cohesive Strength Meter (CSM) and Magnetic Particle Induction (MagPI) to better unravel biologically mediated effects on physical processes in relation to patchiness and rapid changes over emersion periods. Despite their convenience for rapid evaluation of bed adhesion and binding properties of EPS, these tools are not appropriate for quantifying erosion rates, especially when examining the chl- $a$ resuspension, and to evaluate the sediment export by erosion forces. A classical flume study in the field remains appropriate to assess sediment and chl- $a$ erosion rates. Besides, recent methodological advances have enabled more precise quantitative studies of sediment erodibility and the evaluation of bed erodibility. These are due to the refinements of bed sheer stress and roughness quantification, which are applied upon experimented sediments giving systematic estimates during each independent experiment. In addition, a new optimized procedure for EPS extraction has been developed to avoid contamination by cell-internal EPS (Takahashi et al. 2009), and a thorough description of EPS, including protein contents, has consequently been carried out.

\section{Material and Methods}

\section{Study site and environmental descriptors}

The Marennes-Oléron bay, France, consists of vast intertidal areas lined by a semidiurnal macrotidal regime (tidal range of $6 \mathrm{~m}$ ). Within this site, muddy sediments are dominant with an average $88.6 \%$ of silt fraction $(<63 \mu \mathrm{m})$. The sampling site was located in the middle of Montportail-Brouage mudflats, at an intermediary position between the shore and dense mussel-culture farms $\left(45^{\circ} 54^{\prime} 50^{\prime \prime} \mathrm{N}, 01^{\circ} 05^{\prime} 25^{\prime \prime} \mathrm{W}\right)$. Sediment samples were collected during a 13-day period (from July 13 to July 28, 2008) with the aim of surveying microphytobenthos, EPS, and bacteria during complete neap/spring-tide cycles (Orvain et al., 2014). The field was set out as a grid, with sampling areas ( $2 \mathrm{~m}$-side) separated by alleys ( $2 \mathrm{~m}$ in width) were defined. Every day, three squares were randomly chosen to account for spatial heterogeneity. Five cores were sampled within each square, one hour before tidal flow, and the sediment from these were mixed together. The step-by-step increase of currents in the erosion device was synchronized with the in situ flow tide to avoid any bias in terms of MPB 
vertical distribution during the experiments (governed by a chronobiological rhythm). Sediment was monitored in darkness to avoid any production, and to mimic the return of turbid water on the site.

\section{Erosion experiments}

Erosion experiments were performed from July 14 to July 26 with an erosion device ("Erodimetre" in Fig. 1A, Guizien et al., 2012). On each consecutive day, eight cores (9 cm in diameter) of sediments were collected from the field in one of the three squares in which sediment and biofilm parameters were first assessed (see details in Orvain et al., 2014). Core samples where then brought back to the shore by hovercraft, and transported $5 \mathrm{kms}$ to the laboratory. The erosion flume constituted of a small transparent flume $(1.20 \mathrm{~m}$ long, $10 \mathrm{~cm}$ wide and $2 \mathrm{~cm}$ high) where an unidirectional flow could be generated (Fig. 1A). The sediment samples (two cores chosen from the eight taken in the field) were inserted into the bottom of the flume at the time tidal flow reached the sampling site in the field (see Le Hir et al., 2008 for a complete description of this procedure), and the circuit was filled with filtered seawater. Flow speed above the sediment was controlled by a recirculation pump frequency regulator (Fig. 1C). Once the sediment and water were set in the flume, the flow was steadily increased until the eroded surface became too rough to keep sufficient control of the BSS (up to $\sim 15 \mathrm{~Pa}$, see Fig 1C). Flow discharge was increased by increments of $0.0633{\mathrm{~L} . \mathrm{s}^{-1}}^{-1}$, from 0.12 to 2.02 L. ${ }^{-1}$. Each experiment consisted of two phases: 1) when sediment erosion was low, and the flow discharge was increased every two minutes; and 2) after that the bed mass erosion occurred, the flow discharge was increased every five minutes. The steps were lengthened as soon as the erosion was visually observed at the surface of sediment. Longer steps were applied at higher flow speeds to ensure that the total quantity of erodible sediment at each discharge step was eroded. BSS, which not only depends on flow velocity but also on bottom roughness, which was derived independently from flow velocity using pressure head loss measurements (Guizien et al., 2012).

Flow discharge and the turbidity were continuously recorded. The erosion of fine particles was estimated by a nephelometric probe (NTU) that was systematically calibrated by direct comparison to water samples. A sample of $0.5 \mathrm{~L}$ was filtered at four different flow levels to measure the total mass of dry sediment retained on previously weighed filters (Whatman GFC). The same volume was filtered for chl- $a$ concentration in the seawater. Turbidity data were calibrated from filtered suspended particle matter (SPM) concentrations $(\mathrm{g} / \mathrm{L})$, which were converted upon the basis of the most appropriate calibration curve (NTU versus SPM). A linear regression was used for calibrating the turbidity data to provide the best fit $\left(\mathrm{R}^{2}>0.92\right)$, while a polynomial regression was used for chl- $a\left(\mathrm{R}^{2}=0.99\right)$. SPM data were also corrected to account for the dilution effect, since $2 \mathrm{~L}$ of the sampling was used for filtration at four successive steps all along the erosion experiment, and the same quantity of filtered water was added to maintain the volume in the system.

By analysing separately turbidity and chl- $a$ erosion data, the critical threshold for erosion and erosion rates were deduced from the time-derivative curve, after calibration, and correction for dilution effects (Fig. 1B). The mass of eroded sediment was computed as the product of turbidity concentration $\left(\mathrm{g} . \mathrm{L}^{-1}\right)$ multiplied by the water volume $(15 \mathrm{~L})$, divided by the sediment area $\left(=2 \pi \times 0.045^{2}\right.$ in $\left.\mathrm{m}^{2}\right)$. An example (July 22) is given in Fig. 2B to better illustrate the procedure. Critical thresholds for erosion were calculated by determining the intersection point with $\mathrm{X}$-axis when drawing a regression line between SPM (averaged for each flow step) versus $\log \left(\mathrm{U}^{*}+1\right)$ (Sutherland et al., 1998):

$$
\mathrm{SPM}=\mathrm{A} \times \log \left(\mathrm{u}^{*}+1\right)+\mathrm{B}
$$


where $\mathrm{u}^{*}$ is the shear velocity (square root of BSS divided by seawater density, in $\mathrm{m} \cdot \mathrm{s}^{-1}$ ). After defining the parameters A and B of the best regression line (with the highest $\mathrm{r}^{2}$ ), the number of points was increased when considering values from the last flow step to the first one. The best regression line was retained, and the erosion rate was determined by considering only flow steps, for which the critical BSS ( $\left.\tau_{\text {crit-sed }}\right)$ was extrapolated (data from the last steps exhibiting a reduction of erosion rate due to the finite volume of sediment in the core were discarded). The critical value of BSS for erosion was calculated by using the usual formulation between $\mathrm{u}^{*}$ and $\tau_{\mathrm{f}}$, the BSS: $\tau_{\text {crit-sed }}=\rho \cdot \mathrm{u}_{\text {crit }}{ }^{* 2}$. The same procedure was applied to chl- $a$ erosion data to determine the critical threshold for chl- $a$ erosion $\tau_{\text {crit-chla. This parameter was systematically }}$ lower for chl- $a$ than for sediment (Fig. 1B). For the concerned BSS steps (i.e. for BSS larger than the critical one), the rate of erosion of fine particles $\left(E_{\text {sed }}\right)$ was deduced from the time derivative of the turbidity curve. Erosion rates (in $\mathrm{g} \cdot \mathrm{m}^{-2} \cdot \mathrm{s}^{-1}$ for sediment) were assessed at each step (after incipient erosion point) as the slope between the specific eroded mass of sediment (i.e SPM converted in g. $\mathrm{m}^{-2}$ ) and $\Delta \mathrm{t}$, the time interval between each turbidity record $(1 \mathrm{sec})$. The averaged erosion rate was calculated from the different values calculated per step. Chl-aerosion rates were also calculated and expressed in $\mu \mathrm{g} \cdot \mathrm{m}^{-2} \cdot \mathrm{s}^{-1}$, but with 2 different values: 1) Echla-fluff calculated as the averaged erosion rate for $\tau_{\text {crit-chla }}<\mathrm{BSS}<\tau_{\text {crit-sed; }}$ and 2 ) $\mathrm{E}_{\text {chla-mass }}$ concerning mass erosion phase i.e. when BSS $>\tau_{\text {crit-sed. }}$

\section{Acoustic Doppler Velocimeter measurements}

A single-point acoustic Doppler velocimeter (ADV) from Nortek, measured the 3D velocity at $15.6 \mathrm{~cm}$ a.b. (above bottom, outside the wave boundary layer) and pressure, as soon as the tide level was higher than $50 \mathrm{~cm}$ at the location $45.9161^{\circ} \mathrm{N}, 1.0890^{\circ} \mathrm{W}$ (Fig. 1). Thus, ADV data collection was interrupted during low tides. Measurements consisted of 2 min $30 \mathrm{~s}$ time series recorded every $15 \mathrm{~min}$ at a frequency of $32 \mathrm{~Hz}$ for the three velocity components and pressure. Turbulent Reynolds shear stresses outside the wave boundary layer were computed as the covariance of horizontal and vertical velocity deviations from the mean flow after removing wave-induced velocities. Wave-induced velocities were computed by applying a $0.5 \mathrm{~Hz}$ low pass filtering on raw velocity measurements (Guizien et al., 2010). Assuming a logarithmic boundary layer, BSS associated with the tidal current was then linearly extrapolated to the bed using Reynolds sheer stress measured at $15.6 \mathrm{~cm}$ a.b., and zero Reynolds sheer stress at the free surface.

Wave density spectra were computed from pressure time series sub-sampled at $4 \mathrm{~Hz}$, and used to derive the wave parameters [(mean spectral period (Tm) and significant height $(\mathrm{Hs})]$ over the Brouage mudflats. Assuming that the wave field was uniform over the mudflats, wave orbital velocities at $40 \mathrm{~cm}$ a.b. were derived from Tm and Hs, according to the linear wave theory for varying water depths D along the tidal immersion. The time-varying BSS associated with a sine wave with the same orbital velocities was computed using a parameterized formula (Guizien and Temperville, 1999). Here, bed roughness was taken as being equal to $0.5 \mathrm{~cm}$, based on the biogenic roughness height, which could be visually estimated on the mudflat. BSS associated with waves ( $\left.\tau_{\text {field }}\right)$ during the immersion period was taken as the average of this time-varying BSS, and was always larger than the BSS associated with the tidal current-only.

\section{Statistics}

Multiple regression approach was also performed to select explanatory variables among all ecological parameters (Water content, median particle diameter, bacteria abundance, $1^{\text {st }} \mathrm{cm}$ chl- $a$ concentration, $1^{\text {st }} \mathrm{mm}$ chl- $a$ concentration, EPS contents, Peringia ulvae density) that could primarily explain the variation of erodibility (critical thresholds for 
erosion and erosion rates). A systematic approach was tested to search for the best regression model upon separate datasets (MINITAB release 15). A simple Pearson's correlation test was performed to better illustrate the relationships, and scatter-plots between explanatory sediment descriptors and erodibility parameters (chl- $a$, and sediment critical BSS; chl- $a$, and sediment erosion rate)

\section{Results}

\section{Erosion kinetics}

The bulk sediment was systematically eroded after chl- $a$ erosion was initiated at the relatively low BSS of $1.78 \pm 0.78 \mathrm{~Pa}$ (Table 1). Mass erosion occurred when higher BSS was applied above the critical thresholds of $5.21 \pm 1.68 \mathrm{~Pa}$. The same extent of variation affected the critical thresholds of sediment bulk matrix and chl- $a$ biomass in the $1^{\text {st }} \mathrm{cm}$ of sediment (32.8 and $43.8 \%$, respectively).

Flow velocity was linearly increased in the flume and BSS was measured (Fig. 1B) at the same time as turbidity and chl- $a$ concentration in the water column (Fig. 1C). The results of July 22 clearly illustrated the typical succession of the two erosion types (Fig. 1B). During each erosion experiment, BSS increased following a quadratic law as a function of time (and so as a function of the linear increase of flow velocity that was applied in the device) before mass erosion happened (at 400 seconds in Fig. 1C). The prior stage, with the quadratic increase of BSS, followed the expected hydrodynamic response according to classical BSS dimensional parameterization. After mass erosion, BSS's increase shifted to a linear dependence with time, evidencing that core roughness was no longer constant in time. Moreover, slope of BSS versus time decreased on July 22, most probably because of a decrease in bed roughness caused by smoothing effects of erosion processes that erased bed irregularities. Conversely, during some erosion experiments, the subsequent erosion stages after this reduction were accompanied by a final sharp increase of BSS when sediment disruption was affected by holes appearing in the sediment matrix. This observation strongly reflected the dynamical and interactive effects between erosion and tidal flow.

Before mass erosion occurred, a few particles, which detached from the sediment matrix, were found to be especially enriched in benthic diatoms, as indicated by the chl- $a$ concentration increase. This process can be attributed to the early erosion stages of a biogenic fluff layer, as observed in previous studies on this site (Orvain et al. 2007, 2012), in relation with reconstructed sediment by macrofauna inhabiting the habitat of this mudflat (Orvain et al. 2004). Erosion during this early stage of erosion was defined by increasing fluorescence, while turbidity accumulation in the water column was not detectable by the NTU sensor.

\section{Erodibility dynamics}

Surprisingly, there was no significant correlation between critical thresholds for surface and mass erosion, either regarding sediment, or chl $a$. For instance, there were experiments revealing a relatively high resistance, but erosion rates did not increase with the critical threshold (contrary to what is often reported in literature, where high erosion rates are often observed when bed fails suddenly at high stresses in diatom stabilized areas for example). Nevertheless, there was a positive and significant correlation between erosion rates from chl- $a$ and sediment during the second phase of mass erosion $(\mathrm{R}=0.58 ; \mathrm{P}<0.05)$, indicating that chl- $a$ resuspension directly reacted to mass erosion of the sediment when bed failure occurred.

The net distinction between the two erosion types (surface and mass) was also confirmed by the absence of correlation between erosion rates of chl- $a$ biomass during the 
two subsequent erosion phases. However, chl- $a$ and sediment erosion responded to similar temporal dynamics (Figs. 2A and 2B) since there was also a positive and significant correlation between chl- $a$ and sediment erosion thresholds during the two subsequent phases $(\mathrm{R}=0.68 ; \mathrm{P}<0.01)$. In fact, there was a trend of general erodibility related to the tidal emersion timing during the day. The period of emersion at the beginning of the afternoon (Table 2), at the middle of the survey, was characterized by high resistance to erosion, similar to of July 20, $23 \& 24$ (critical BSS > $8 \mathrm{~Pa}$; Table 1). Conversely, the two periods of emersion early in the morning and late in the afternoon (Table 2), at the beginning and the end of the survey, was characterized by lower resistance in terms of critical thresholds similar to July 17 \& 25 (Fig. 3A). However, this remains a loose trend, since there was no direct relationship between tidal amplitude and any erodibility parameter.

Erosion rates of chl- $a$ were always higher for mass erosion than for fluff layer erosion (Fig. 3B), except on July 21, when the lowest chl- $a$ concentration value was recorded for the 13 days in the $1^{\text {st }} \mathrm{cm}$ depth (Table 2 ); along with a low sediment stability observation.

\section{Relationship with environmental factors}

Information regarding the environmental, biogeochemical parameters, and distribution of benthic diatom and mobile fauna, is given in Orvain et al. (2014). In this manuscript the outcomes for understanding their potential roles in the control of erodibility parameters are discussed. Environmental factors and data regarding biofilm features, as well as motile infauna, are given at the end of the exposure period before tidal flow returns, since they constitute a set of factors that could control bed erodibility.

Multiple regressions revealed that sediment variables, like the water content or the sediment bulk density, did not play an important role for explaining the temporal variations of bed and fluff layer erodibility during the 13 consecutive days of the study period (Table 3). It must be mentioned however, that the water content was especially stable, averaging around the $50 \%$ value, with only $2 \%$ of variation (Table 2 ). The 13 -day period was characterized by remarkable sunny weather, disturbed only by some clouds towards the end. This explains why the water content of a pure mud with a median diameter of $11 \mu \mathrm{m}$ at a low level was so stable (Table 2). Nevertheless, the model of multiple regression that was retained after a systematic approach included the median diameter of sediment particles, but this variable took only a minor rank after pheopigment concentration in sediments and fauna abundance. The single other environmental factor that appeared in the set of explanatory variables was the salinity of interstitial porewater, itself a good proxy for sediment desiccation. Salinity was included in the multiple regression model regarding type II mass erosion ( $\left.E_{S E D}-m a s s\right)$. Once again, the contribution of this factor was minor, ranked $3^{\text {rd }}$, after two biological factors. Salinity was also detected as an explanatory factor regarding chl- $a$ erosion rate during the fluff layer erosion ( $E_{\text {chla-fluff }}$, but ranked $3^{\text {rd }}$, after two other variables. Even though the sampling design was developed for detecting tidal influence along an almost complete 14-day spring/neap tidal lunar signal, the tidal amplitude failed to reveal any effects on erodibility regarding the two erosion types (in spite of the general tendency that appeared in Fig. 3A and 3B).

\section{Relationships with motile infauna}

The dominant species from the infaunal assemblage was the gastropod Peringia ulvae. With very high densities and spatio-temporal dynamic variance (averaging $~ 20.000$ ind. $\mathrm{m}^{-2}$ ), it was affected by a variation of $31 \%$ (Table 2). It must be mentioned, that the cores sampled for snail enumeration were taken close to the cores for the erosion experiments. This was to limit the risk of spatial distribution heterogeneity bias, while caution was taken to remain within the same patch of snail distribution. There was a negative relationship between critical thresholds for fluff layer erosion of chl- $a$ and snail density. This variable was ranked $2^{\text {nd }}$ after 
another variable also related to grazing effects caused by snails - the pheopigment concentration (Fig. 4A; see further discussion). The erosion rate of chl- $a$ during this fluff layer erosion was significantly and negatively related to chl- $a$ concentration in the $1^{\text {st }} \mathrm{cm}$, even though the values of this variable remained very low (Table 2; Fig. 4B). This can only be explained by the strong negative influence of grazers on the chl- $a$ concentration that eventually had an effect on the surficial chl- $a$ erosion rate. Benthic chl- $a$ and snail density were also negatively correlated $(\mathrm{R}=-0.22, \mathrm{P}<0.05)$.

\section{Relationships with ExoPolymeric Substances (EPS) and benthic diatoms}

The extent of variation regarding carbohydrate EPS was higher than $20 \%$. Despite proteins representing only a small proportion of EPS compared to carbohydrates $(\sim 10 \%)$, they were subjected to a higher amount of variation since the percentage of error (i.e. temporal variability) attained almost $35 \%$ of the average for the bound fraction. The percentage of error of chl- $a$ concentration at the two vertical scales $\left(1^{\text {st }} \mathrm{mm}\right.$ and $\left.1^{\text {st }} \mathrm{cm}\right)$ reached only $13 \%$ and $8 \%$, respectively. The single explanatory factor for the critical threshold for mass erosion ( $\left.\tau_{\text {crit-SED}}\right)$ was the bound EPS proteins (Table 3 ) with a negative but a very weak relationship $(\mathrm{P}=0.09$; Fig. $4 \mathrm{C})$. The rapid decrease of this variable after the first day of the survey was followed by a continuous and gradual increase. The critical threshold for erosion $\left(\tau_{\text {crit-SED }}\right)$ showed an opposite pattern (Fig. 3A). Bound EPS were also the best explanatory factor regarding erosion rates of sediment (Fig. 4D), with a positive relationship with carbohydrates. There were other factors related to microphytobenthos, and explanations for the variation of erosion rates such as the $1^{\text {st }} \mathrm{cm}$ chl- $a$ concentration (Table 3 ), but those relationships were negative.

No variables explained the variation of chl- $a$ erosion rates during mass erosion (even though chl- $a$ and sediment erosion rate were significantly and positively correlated together), probably because this parameter relies on an interaction between sediment properties and microphytobenthos-macrozoobenthos feedback mechanisms.

\section{Microphytobenthos and sediment erosion.}

Beyond erodibility, the net export was assessed by comparing maximum BSS measured on the site and erodibility kinetics (sediment erosion vs. BSS kinetics). When analysing the variation of this net export flux, there was neither a tendency nor a pattern that could be attributed to a specific factor, regarding the variability of resuspended chl- $a$ and sediment (Fig. 5). There was a positive correlation between the signals of resuspended sediment and microphytobenthos $(\mathrm{R}=0.92, \mathrm{P}<0.001)$. The amount of daily exported material relies upon erodibility changes $\left(\tau_{\text {crit-SED }}\right)$, as well as hydrodynamics disturbance, due to wave-induced BSS $\left(\tau_{\mathrm{f}}\right)$. Wave-induced BSS showed moderate values (2.45 Pa on average), larger than the threshold for chl- $a$ erosion, but lower than the threshold for mass erosion. During this summer survey, waves built up during the day under the action of a moderate thermal wind coming from the sea (less than $10 \mathrm{~m} . \mathrm{s}^{-1}$ ), and died down every night. As a result of between-days variation in diurnal and nocturnal temperatures contrast, waves did not exhibit a clear periodic pattern, even though the maximal value of $4.2 \mathrm{~Pa}$ was recorded on July 21 (i.e. the maximum spring tide).

There was a perfect synchronisation between the lowest bed stability $\left(\tau_{\text {crit }}\right)$ regarding sediment and chl $a$, with the maximal BSS occurring on the same date i.e. July 21 (Table 1 and fig 5). For these combined reasons, the export sediment and chl- $a$ fluxes were maximal on this date. This was the only date on which mass erosion was observed, and this event was determined by the response of the confrontation of erodibility measurements to field BSS. 
However, this cannot be attributed to any bioengineering processes related to biofilm, since chl- $a$ concentration was at its minimum value on this date.

The total quantity of exported sediment during the whole survey (13 days) remained very limited, totalling 100 g.m ${ }^{-2}$ (i.e. $7780 \mu \mathrm{m}$ when converted using the sediment bulk density). This represents a very limited erosion depth after 13 days (almost a complete spring/neap tidal signal). The very cohesive nature of this sediment along with the desiccation that was observed during the survey must explain the very low sediment export by erosion. Regarding resuspended microphytobenthos, the global net sum of exported chl- $a$ was 10.3 $\mathrm{mg} . \mathrm{m}^{-2}$. Once again, the quantity of resuspended material was extremely low during this 13 day temporal window. On average, only $1.3 \%$ of the standing stock of benthic diatoms was resuspended each day.

\section{Discussion}

\section{Bioturbation, fluff layer and chl-a erosion rate}

Erosion curves show that chl- $a$ biomass was systematically eroded before the general bed failure of the bulk sediment. This feature is typical of a fluff layer erosion at the surface (type 0), this material being clearly characterized by a chl- $a$ enrichment. Only a few studies have addressed the resuspension of benthic diatom and their exportation in the water column (Blanchard et al., 1997; Shimeta et al., 2003). All these studies agree on the fact that benthic diatoms are resuspended before the sediment, likely in relation to their vertical distribution, and their abilities to migrate and form biofilms. Such early recurrent resuspension of MPB without any concomitant sediment erosion was introduced with success in a modeling application in the Marennes-Oléron basin to predict water-column enrichment in chl- $a$ (Guarini et al., 2008). In the field, this early resuspension must also be mediated by their close association to bioturbated layers, and a combination of conditions specific from this material: high water content; dissociation from sediment matrix; enrichment in nutrient by fauna secretion; rapid turnover; and sediment reworking. Fluff layers are created, for instance, by bioturbation activity that can create habitats in favor of a rapid colonisation by diatoms (Orvain et al., 2007). For instance, the mixing process by macrofaunal engineers could amplify the migration rates towards surface for microphytobenthic species. Moreover, the release of nutrients by species destroying the sediment matrix at the surface could also provide an additional source for primary production within the biofilm. Bioturbation and sediment reworking, leads to a sediment turnover favoring the nutrient renewal for the biofilm.

During this field study, detailed analyses of EPS, chl- $a$ concentrations at two different scales $\left(1^{\text {st }} \mathrm{cm}\right.$ and $1^{\text {st }} \mathrm{mm}$ ), as well as environmental factors (water content, salinity, irradiance), suggests that benthic diatoms were affected grazing pressure by the gastropod Peringia ulvae (Orvain et al., this issue). The density of this snail was very high, and in this context, a significant erosion of fluff layer would be expected. In the range of density that was recorded, negative effects of snail activity provoked a decrease of chl- $a$ erosion rates, during fluff layer erosion, as already observed in previous studies on neighboring sites (Orvain et al., 2007). The negative correlation between chl- $a$ biomass in the $1^{\text {st }} \mathrm{cm}$ of sediment and chl- $a$ erosion rates, along with the positive correlations between Pheo/(Pheo + chl $a)$ and critical thresholds of BSS, confirms the prime role that Peringia ulvae played in grazing and control of a fluff layer formation on this intertidal mudflat. Addition evidence of this is pigment content, since pheopigments are a good index of Peringia ulvae grazing (Cartaxana et al., 2003). The snail density also explains part of the variability of the critical thresholds of chl- $a$ during fluff layer erosion. The high densities of Peringia ulvae were thus responsible for a strong decrease in chl- $a$ concentration leading to a positive effect on chl- $a$ erosion rates relating to the formation of the fluff layer, and a negative effect on critical BSS for chl- $a$ 
erosion. Bioturbation effectively increased bed roughness (data not shown), and thus BSS for the same velocity, which only explains fluff layer erodibility increase, but not mass erosion, because bed irregularities and snails were rapidly smoothed at the surface.

The present study confirms that the top-down control by herbivores can provoke a dramatic collapse of chl- $a$ biomass in intertidal mudflat sediments in summer, as already observed in other intertidal mudflats (Weerman et al., 2011). This leads to complex feedbacks, predisposing the ecosystem to rapid shifts in ecological functions (Thrush et al., 2012). This regulation provoked a collapse of chl- $a$ biomass so intense in summer that an event of mass erosion occurred after several days of intense grazing. Erosion processes play an important role in this vegetal-herbivore interaction by reinforcing the drastic decline of the vegetal biomass after a sequence of several days of co-occurring intense grazing by snails, and chl- $a$ decline.

\section{Exopolymeric substances secretion, and sediment erosion}

Water content only showed subtle variations, which did not provoke modification in terms of bed resistance to erosion. However, salinity variations due to strong evaporation of porewater during the present sunny summer study explain some degrees of variation of bed erodibility (but only at minor position in the set of explanatory factors).

In contrast, biotic descriptors of the biofilm displayed large temporal fluctuations along the spring/neap tidal cycle, which could have entailed sediment erodibility fluctuations. The microphytobenthic and bacteria biomasses were positively correlated in the sediment and remained very low, reflecting the top-down regulation due to the high density of Peringia ulvae. The secretion of bound exopolymeric substances (EPS) reflected the constitution of a biofilm rich in glycoproteins. After several days of significant biofilm predation by $P$. ulvae, associated with extreme irradiance, which should have provoked photoinhibition, chl- $a$ concentration strongly decreased in the $1^{\text {st }} \mathrm{cm}$ and $1^{\text {st }} \mathrm{mm}$, and mass erosion occurred at very low BSS. This could be considered as an indirect effect of the long period of intense Peringia ulvae grazing, that could have impaired the biofilm armoring and biostabilising effects; already observed in the field (Andersen, 2001).

In addition, parallel to grazing, desiccation also stimulated the secretion of colloidal EPS to maintain moieties in the surrounding microenvironment of diatoms in relation to osmotic processes on July 21. The EPS secretion effect on physical properties has received considerable attention in past studies, but mechanisms have not been fully unravelled (Tolhurst et al., 2006). EPS consist of heteropolymers that are relatively undefined because they combine molecules of various natures (polysaccharides, proteins, glycoproteins, uronic acids, lipids...etc), and this complexity provokes many problems for extracting and characterizing them, as well as their properties (Underwood and Paterson, 2003). Given the considerable amounts of EPS within sediments, and their complex nature, production patterns and mechanisms responsible for EPS losses (solubilisation, erosion, bacteria degradation, removal by uprising flood, and consumption by fauna) need to be explored in order to understand their role in the environment (Underwood and Paterson, 2003). There are a wide variety of physiological functions attributed to EPS that allow diatom to create an assemblage of favorable microhabitats: adhesion and contribution to vertical movements in sediments; biofilm constitution; surface colonisation; quorum sensing; overflow metabolism (a mechanism activated in case of nutrient stress to remove the excess carbon from their internal structure); protection against extreme conditions (by acting like an external osmoregulator); sequestration of pollutants; nutrients; or low molecular weight organic substances (Decho, 1990; Flemming and Wingender, 2010). We can define at least four fractions of EPS, according to their biochemical composition: 1) Colloidal (slime polymers), considered as residual substances remaining like a ghost of diatom after their departure; 2) bound or 
capsular EPS, considered as the gel that directly surrounds diatom cells; 3) EPS, associated to frustule formation; and 4) internal storage forms (Abdullahi et al., 2006).

In most studies on the effects of EPS on sediment erodibility, these substances have been classically considered as stabilising factors that can increase critical BSS for erosion by reinforcing adhesion between particles (Tolhurst et al., 2006; Underwood and Paterson, 2003). This effect has been confirmed during field measurements in muddy (Sutherland et al., 1998; Tolhurst et al., 2006; Yallop et al., 2000) and mud/sand mixtures (Ubertini, 2012). Proteins of EPS have also been implied in biostabilisation, when examining riverine bacterial assemblages (Gerbersdorf et al., 2008). Yet, in the present study, surprisingly, EPS protein increase was correlated to a decrease of resistance of sediment bed to erosion. This unexpected observation could be attributed to hydrophilic properties of these components of EPS. In some laboratory experiments, it has been shown that most of the time the stabilising effects due to EPS secretion are active during MPB growth phase (Orvain et al., 2004; Tolhurst et al., 2008a). However, there are also some specific conditions related to the absence of benthic diatoms removal, by grazing and/or resuspension processes, which causes changes in EPS nature and production rates. These conditions can also change their properties from stabilising to destabilising effects, when the thickness of the biofilm becomes very high (Orvain et al., 2004; Yallop et al., 2000). This indicates the importance of the quantity of EPS secreted by MPB, as well as their specific biochemistry to unravel their biostabilising effects in association with 3D-microstructural assemblages of biofilms (de Brouwer et al., 2005). Nevertheless, the $1^{\text {st }} \mathrm{mm}$ concentration measurements by using surface fluorescence in relation to biofilm patchiness and EPS carbohydrates does not explain biogenic mediation of bed resistance to physical forcing. This study has shown that the armoring and patchiness effects of biofilms on the variation of bed erodibility cannot be explained. However, EPS seems to explain better erodibility fluctuations, even if the results obtained were contrary to the biostabilising theory. The negative effect of EPS cannot be compared to previous observations in laboratory studies with thick biofilms lacking macrofauna and resuspension (Orvain et al., 2004). The biofilm does not have the same behavior according to seasons, and some specific environmental conditions could provoke unexpected consequences on bed resistance to erosion. The standing stocks of benthic diatoms were so negatively affected by mudsnails. It is therefore speculated whether or not the mucus secretion by these gastropods could explain the increase of bound EPS proteins, since correlation was observed between snail density and the amounts of EPS proteins. This could also explain why the increase of bound proteins was related with a decrease of bed resistance to erosion.

\section{Resuspension of benthic diatoms and sediment transport}

The range of BSS measured in the present study matched that with the modelled BSS (within the range of 1.5-4Pa) on one neighboring site in the Brouages mudflat (Le Hir et al., 2000), displaying wind-waves activity during most of the survey duration.

The relative unpredictability of the sediment and MPB export is not surprising, but raises some specific questions, since current studies are performed with the objectives of simplification and modelling. It must be mentioned that wind-wave BSS reached the same range in winter, since wind effects were observed during our summer survey (data not shown). Ridges from intertidal mudflats appeared very resistant to erosion, as predicted by the very low values of water content. However, desiccation (evidenced by porewater salinity increase) did not appear as a major driver of critical thresholds for bed erosion, and erosion rates fluctuations (at least in the control of the high-frequency variability). It was found that high protein EPS content did not stabilize the sediment, but on the contrary, was related to higher erodibility. These findings could be explained by erodibility enhancement due to snail grazing, and protein EPS content increasing with grazing activity. This effect was also related 
to a significant chl- $a$ decrease after several days, with high densities of motile grazers. This process could explain why mass erosion occurred, if it is considered that armouring effects by biofilm were impaired by a strong top-down regulation exerted by motile snails. The sediment was subjected to mass erosion on this very special occasion recorded on July 21. The estimates of eroded sediment was very low when analysing the global balance during the 13 days, and most of the total quantity of sediment eroded during this time was actually eroded in one single day because of the occurrence of a 'catastrophic' mass erosion. It must be stressed that increased erodibility due to the presence of mudsnails does not necessarily result in a net loss of sediment. The strong pelletisation of the surface bed significantly increases the settling velocity of eroded sediment, which prevents sediment from being exported from the basin due to the rapid settling on mudflats (Andersen et al., 2005).

The assessment of resuspension rates of benthic diatoms was directly carried out on this field site for the first time. Results showed the export of benthic diatoms to pelagic food webs remained limited for the season, in the meteorological context of the present survey. Such a low export was due to relatively low biomasses of benthic diatoms after a strong grazing pressure and a low primary production, probably impaired by photoinhibition. Chl- $a$ export was particularly low compared to extrapolated quantification in models of diatom growth on this site in spring. For instance, Guarini et al. $(2000,2008)$ estimated that $10 \%$ of benthic diatoms are resuspended when the tide is rising. The value of chl- $a$ biomass was already extremely low, and the proportion of resuspended chl- $a$ was also very low. For these two reasons, the quantity of chl- $a$ biomass that was resuspended was very low compared to model estimations (Guarini et al., 2008), or extrapolation from short-term temporal pattern of chl- $a$ biomass in the sediment in 1998 (Blanchard et al., 2001). The two main sources of losses of microphytobenthic biomass on this site could be attributed to: 1) intense grazing by Peringia ulvae (Blanchard et al., 2001); or 2) tide and/or wave induced resuspension. When the consummation rate by the gastropod is very intense, as seems to be the case in the present study, the second source of chl- $a$ loss (i.e. resuspension) appears to become very low.

In this study, export only reached $2.5 \%$ of the total standing stock in terms of $1^{\text {st }} \mathrm{cm}$ chl- $a$ concentration, even though wind-wave activity promoted large BSS during half of the survey. This not only suggests seasonal variations of MPB standing stock, but also that erodibility should be taken into account when forecasting MPB export. In winter, larger export could be expected from a higher standing stock of benthic diatoms combined with higher BSS during storms (see Orvain et al, 2014). Such fluctuations in MPB export was modelled as a disturbance ('catastrophic erosion') in addition to frequent microphytobenthos 'tidal erosion' in normal condition (i.e. 'not catastrophic', see Mariotti and Fagherazzi, 2012). The present study could help to refine this concept since only a 'chronic' fluff layer erosion occurs in normal conditions (without mass erosion of the sediment matrix). Also, the microphytobenthos resuspension does not directly reflect the tidal or even wave-induced modulation of the BSS, but rather reflects the erodibility changes resulting from bioturbation intensity and grazing pressure by motile infauna (and Peringia ulvae the dominant species from the site). 


\section{Conclusion}

The initial assumption, according to which microphytobenthic biofilms primary production and exportation in the water column are stimulated in summer, and can be predicted as a function of tidal/light conditions and regulated by EPS bioengineering sediment, is completely invalid. In this context, it was observed that the proteins from bound EPS were negatively correlated to critical threshold mass erosion, apparently contradicting biostabilisation theory by benthic diatoms and associated EPS. However, this could be related to mucus secretion, which would explain in part the proteins observed in bound EPS. Topdown regulation exerted by consumers of benthic diatoms was so intense in summer on this site that chl- $a$ biomass was strongly and negatively affected. After several days of the drastic decrease in chl- $a$ biomass in the sediment, and limited fluff layer erosion, whose resuspension rates were positively correlated to grazing indicators (snail density, pheopigment concentration but probably also bound EPS proteins), sediment shifted to 'catastrophic' mass erosion with a general bed disruption registered on one single day. The story of bed and chl- $a$ erodibility during a sequence of several days clearly stressed the strong influence of the dense Peringia ulvae population on the Marennes-Oléron mudflats. The ecological function of MPB as a trophic fuel for pelagic sub-system after resuspension seems to follow the idiosyncratic response, in spite of bioengineering processes, due to its relative lack of predictability and spatial/temporal complexity (fig. 5). Even though desiccation effects were not detected in correlation tests, it is supposed that this process fully explains this summer context, with dominant top-down processes controlling chl- $a$ and sediment properties.

\section{Bibliography}

Abdullahi AS, Underwood, G.J.C., Gretz, M.R., 2006. Extracellular matrix assembly in diatoms (Bacillariophyteae). V. Environmental effects on polysaccharide synthesis in the model diatom Phaedactylum tricornutum 378, 363-378.

Andersen, T.J., 2001. Seasonal Variation in Erodibility of Two Temperate, Microtidal Mudflats. Estuarine, Coastal and Shelf Science 53, 1-12.

Andersen, T.J., Lund-Hansen, L.C., Pejrup, M., Jensen, K.T., Mouritsen, K.N., 2005. Biologically induced differences in erodibility and aggregation of subtidal and intertidal sediments: a possible cause for seasonal changes in sediment deposition. Journal of Marine Systems 55, 123-138.

Andersen, T.J., Pejrup, M., 2002. Biological Mediation of the Settling Velocity of Bed Material Eroded from an Intertidal Mudflat, the Danish Wadden Sea. Estuarine, Coastal and Shelf Science 54, 737-745.

Blanchard, G., Simon-Bouhet, B., Guarini, J., 2002. Properties of the dynamics of intertidal microphytobenthic biomass. Journal of marine biological Association UK 82, 1027 1028.

Blanchard, G.F., Sauriau, P.-G., V Cariou-le Gall, Gouleau, D., Garet, M.-J., Olivier, F., 1997. Kinetics of tidal resuspension of microbiota : testing the effects of sediment cohesiveness and bioturbation using flume experiments. Marine Ecology Progress Series 17-25. 
de Brouwer, J.F.C., Wolfstein, K., Ruddy, G.K., Jones, T.E.R., Stal, L.J., 2005. Biogenic stabilization of intertidal sediments: the importance of extracellular polymeric substances produced by benthic diatoms. Microbial ecology 49, 501-12.

Cartaxana, P., Jesus, B., Brotas, V., 2003. Pheophorbide and pheophytin a-like pigments as useful markers for intertidal microphytobenthos grazing by Hydrobia ulvae. Estuarine, Coastal and Shelf Science 58, 293-297.

Decho, A.W., 1990. Microbial exopolymer secretions in ocean environments: their role(s) in food webs and marine processes. Oceanographic marine biology annual Review 28, 73 153.

Flemming, H.-C., Wingender, J., 2010. The biofilm matrix. Nature reviews. Microbiology 8, 623-633.

Gerbersdorf, S.U., Manz, W., Paterson, D.M., 2008. The engineering potential of natural benthic bacterial assemblages in terms of the erosion resistance of sediments. FEMS microbiology ecology 66, 282-94.

Guarini, J., Blanchard, G., Gros, P., Gouleau, D., Bacher, C., 2000. Dynamic model of the short-term variability of microphytobenthic biomass on temperate intertidal mudflats. Marine Ecology Progress Series 195, 291-303.

Guarini, J.-M., Sari, N., Moritz, C., 2008. Modelling the dynamics of the microalgal biomass in semi-enclosed shallow-water ecosystems. Ecological Modelling 211, 267-278.

Guizien, K., Charles, F., Hurther, D., Michallet, H., 2010. Spatial redistribution of Ditrupa arietina (soft bottom Mediterranean epifauna) during a moderate swell event. Continental Shelf Research 30, 239-251.

Guizien, K., Orvain, F., Duchêne, J.-C, Le Hir, P., 2012. Accounting for Rough Bed Friction Factors of Mud Beds as a Result of Biological Activity in Erosion Experiments. Journal of Hydraulic Engineering 138, 979-984.

Guizien, K., Temperville, A., 1999. Frottement de fond sous une houle irrègulière linéaire. C.R. Acd. Sci. Paris, Série IIb 327, 1375-1378.

Herman, P., Middelburg, J., Widdows, J., Lucas, C., Heip, C., 2000. Stable isotopes as trophic tracers: combining field sampling and manipulative labelling of food resources for macrobenthos. Marine Ecology Progress Series 204, 79-92.

Herman, P.M.J., Middelburg, J.J., Heip, C.H.R., 2001. Benthic community structure and sediment processes on an intertidal flat: results from the ECOFLAT project. Continental Shelf Research 21, 2055-2071.

Le Hir, P., Cann, P., Waeles, B., Jestin, H., 2008. Erodibility of natural sediments: experiments on sand / mud mixtures from laboratory and field erosion tests, in: Kusuda, T., Yamanishi, H., GJ, S., GailanI, J. (Eds.), Sediment and Ecohydraulics: INTERCOH 2005. pp. 137-155. 
Lubarsky, H.V., Gerbersdorf, S.U., Hubas, C., Behrens, S., Ricciardi, F., Paterson, D.M., 2012. Impairment of the Bacterial Biofilm Stability by Triclosan. Plos one 7, e31183. doi:10.1371.

Lucas, C.H., Widdows, J., Brinsley, M.D., Salkeld, N., Herman, P.M.J., 2000. Benthic-pelagic exchange of microalgae at a tidal flat . 1. Pigment analysis. Marine Ecology Progress Series 196, 59-73.

Mariotti, G., Fagherazzi, S., 2012. Modeling the effect of tides and waves on benthic biofilms. Journal of Geophysical Research 117, G04010.

Murphy, R.J., Tolhurst, T.J., 2009. Journal of Experimental Marine Biology and Ecology Effects of experimental manipulation of algae and fauna on the properties of intertidal soft sediments. Journal of Experimental Marine Biology and Ecology 379, 77-84.

Orvain F., De Crignis, M., Guizien, K, Lefebvre,,S., Mallet, E., Takahashi, E., Dupuy, C. Tidal and seasonal effects on the short-term temporal patterns of bacteria, microphytobenthos and exopolymers in natural intertidal biofilms (Brouage, France). Journal of Sea Research, this issue.

Orvain, F., Galois, R., Barnard, C., Sylvestre, A., Blanchard, G., Sauriau, P.-G., 2003. Carbohydrate production in relation to microphytobenthic biofilm development: an integrated approach in a tidal mesocosm. Microbial ecology 45, 237-251.

Orvain, F., Sauriau, P., Sygut, a, Joassard, L., Le Hir, P., 2004. Interacting effects of Hydrobia ulvae bioturbation and microphytobenthos on the erodibility of mudflat sediments. Marine Ecology Progress Series 278, 205-223.

Orvain, F., Sauriau, P.-G., Le Hir, P., Guillou, G., Cann, P., Paillard, M., 2007. Spatio-temporal variations in intertidal mudflat erodability: Marennes-Oléron Bay, western France. Continental Shelf Research 27, 1153-1173.

Pilditch, C.A., Widdows, J., Kuhn, N.J, Pope, N.D., Brinsley, M.D., 2008. Effects of low tide rainfall on the erodability of intertidal cohesive sediments. Continental Shelf Research $28,1854-1865$.

Shimeta, J., Amos, C., Beaulieu, S., Katz, S., 2003. Resuspension of benthic protists at subtidal coastal sites with differing sediment composition. Marine Ecology Progress Series 259, 103-115.

Shimeta, J., Amos, C.L., Beaulieu, S.E., Ashiru, O.M., 2002. Sequential resuspension of protists by accelerating tidal flow: Implications for community structure in the benthic boundary layer. Limnology and Oceanography 47, 1152-1164.

Sutherland, T.F., Amos, C.L., Grant, J., 1998. The effect of buoyant biofilms on the erodibility microtidal estuary of sublittoral sediments of a temperate Lunenburg Bay. Limnology and oceanography 43, 225-235. 
Takahashi, E., Goux, D., Orvain, F., 2009. Optimising extraction of extracellular polymeric substances (EPS) from benthic diatoms: comparison of the efficiency of six EPS extraction methods. Marine and freshwater research 60, 1-10.

Thrush, S.F., Hewitt, J.E., Lohrer, A.M., 2012. Interaction networks in coastal soft-sediments highlight the potential for change in ecological resilience. Ecological applications 22, 1213-1223.

Tolhurst, T.J., Consalvey, M., Paterson, D.M., 2008a. Changes in cohesive sediment properties associated with the growth of a diatom biofilm. Hydrobiologia 596, 225-239.

Tolhurst, T.J., Defew, E.C., Brouwer, J.F.C.D., Wolfstein, K., 2006. Small-scale temporal and spatial variability in the erosion threshold and properties of cohesive intertidal sediments. Continental Shelf Research 26, 351-362.

Tolhurst, T.J., Jesus, B., Brotas, V., Paterson, D.M., 2003. Diatom migration and sediment armouring - an example from the Tagus Estuary, Portugal. Hydrobiologia 503, 183-193.

Tolhurst, T.J., Watts, C.W., Vardy, S., Saunders, J.E., Consalvey, M.C., Paterson, D.M., 2008b. The effects of simulated rain on the erosion threshold and biogeochemical properties of intertidal sediments. Continental Shelf Research 28, 1217-1230.

Ubertini, M., 2012. Déterminisme de la remise en suspension de la matière organique issue du sédiment dans les écosystèmes conchylicoles bas-normands. 191 pp, Université de Caen Basse-Normandie.

Underwood, G., Paterson, D., 2003. The importance of extracellular carbohydrate production by marine epipelic diatoms. Advances in botany research 40, 183-240.

Weerman, E., Herman, P.M., Johan, V. de K., 2011. Top-down control inhibits spatial selforganization of a patterned landscape. Ecology 92, 487-495.

Widdows, J., Brown, S., Brinsley, M.D., Salkeld, P.N., Elliott, M., 2000. Temporal changes in intertidal sediment erodability: influence of biological and climatic factors. Continental Shelf Research 20, 1275-1289.

Wood, R., Widdows, J., 2002. A model of sediment transport over an intertidal transect, comparing the influences of biological and physical factors. Limnology and Oceanography 47, 848-855.

Yallop, M., Paterson, D., Wellsbury, P., 2000. Interrelationships between rates of microbial production, exopolymer production, microbial biomass, and sediment stability in biofilms of intertidal sediments. Microbial ecology 39, 116-127. 
Table 1: Values of the different erodibility parameters measured at the end of emersion during 13 days in July 2008 (SE: Standard error)

\begin{tabular}{|c|c|c|c|c|c|}
\hline July & $\begin{array}{c}\text { Critical } \\
\text { threshold for } \\
\text { Chl a fluff layer } \\
\text { erosion ( } \mathrm{Pa} \text { ) }\end{array}$ & $\begin{array}{c}\text { Chl a erosion } \\
\text { rate } \\
\left(\mu \mathrm{g} \cdot \mathrm{m}^{-2} \cdot \mathrm{s}^{-1}\right)\end{array}$ & $\begin{array}{c}\text { Critical } \\
\text { threshold for } \\
\text { sediment mass } \\
\text { erosion } \\
(\mathrm{Pa})\end{array}$ & $\begin{array}{c}\text { Sediment erosion } \\
\text { rate } \\
\left(\mathrm{mg} \cdot \mathrm{m}^{-2} \cdot \mathrm{s}^{-1}\right)\end{array}$ & $\begin{array}{c}\text { Chl a erosion } \\
\text { rate } \\
\left(\mu \mathrm{g} \cdot \mathrm{m}^{-2} \cdot \mathrm{s}^{-1}\right)\end{array}$ \\
\hline & \multicolumn{2}{|c|}{ FLUFF LAYER EROSION } & \multicolumn{3}{|c|}{ MASS EROSION } \\
\hline 14 & 0.57 & 0.23 & 3.87 & 6.61 & 0.68 \\
\hline 15 & 1.59 & 0.42 & 4.72 & 88.5 & 0.86 \\
\hline 16 & 1.81 & 0.50 & 4.58 & 9.3 & 1.00 \\
\hline 17 & 2.52 & 0.75 & 5.87 & 155.3 & 1.24 \\
\hline 18 & 2.06 & 0.28 & 8.39 & 90.5 & 0.81 \\
\hline 19 & 1.96 & 0.74 & 4.70 & 87.9 & 1.72 \\
\hline 20 & 4.45 & 0.37 & 8.33 & 77.7 & 0.82 \\
\hline 21 & 0.81 & 1.15 & 2.20 & 27.7 & 0.50 \\
\hline 22 & 1.53 & 0.20 & 3.70 & 60.5 & 1.21 \\
\hline 23 & 1.42 & 0.08 & 8.69 & 28.4 & 0.68 \\
\hline 24 & 1.06 & 0.13 & 5.62 & 47.8 & 0.81 \\
\hline 25 & 0.60 & 0.29 & 1.36 & 79.0 & 0.79 \\
\hline 26 & 2.79 & 0.39 & 5.70 & 95.7 & 1.56 \\
\hline \multirow{2}{*}{$\begin{array}{c}\text { Mean } \\
\text { SE }\end{array}$} & 1.78 & 0.42 & 5.21 & 72.4 & 0.98 \\
\hline & 0.78 & 0.22 & 1.68 & 28.5 & 0.26 \\
\hline$\%$ of & 43.8 & 52.0 & & & \\
\hline error & & & 32.2 & 39.4 & 27.1 \\
\hline
\end{tabular}


Table 2 : Values of the different variables measured at the end of emersion during the 13 days of the erosion survey in July 2008 (SE : Standard error); LT time: Low-tide time; $\mathrm{D}_{\text {median }}(\mu \mathrm{m})$ : Grain size median diameter; $1^{\text {st }} \mathrm{cm} \mathrm{Chl} a$ and $1^{\text {st }} \mathrm{mm} \mathrm{Chl} a\left(\mathrm{mg} \cdot \mathrm{m}^{-2}\right):$ Chl $a$ concentration at the two different depth; Coll carb: Carbohydrate content of colloidal EPS (mg.g DW sediment ${ }^{-1}$ ); Bound carb : Carbohydrate content of bound EPS (mg.g DW sediment ${ }^{-1}$ ); Coll prot : Protein content of colloidal EPS (mg.g DW sediment ${ }^{-1}$ ); Bound prot : Protein content of bound EPS (mg.g DW sediment ${ }^{-1}$ ); Snail density : Peringia ulvae density (ind. $\left.{ }^{-2}\right)$; pheo : Pheopigment percentage from total pigments $($ Pheo $/($ Pheo + chl a) $\times$ 100 in \%); Salinity : Porewater salinity (\%o); Bacteria: Bacteria abundance $\left(10^{9}\right.$ cell. $\left.\mathrm{mL}^{-1}\right)$; Water content: Porewater content $(\%)$

\begin{tabular}{|c|c|c|c|c|c|c|c|c|c|c|c|c|c|}
\hline \multirow[t]{2}{*}{ July } & \multirow[t]{2}{*}{ LT time } & \multirow[t]{2}{*}{$D_{\text {median }}$} & \multirow[t]{2}{*}{$1^{\mathrm{st}} \mathrm{cm} \mathrm{Chl} \mathrm{a}$} & \multirow{2}{*}{$\begin{array}{c}1^{\text {st }} \mathrm{mm} \mathrm{Chl} \\
a\end{array}$} & \multicolumn{4}{|c|}{ EPS } & \multirow{2}{*}{$\begin{array}{c}\text { Snail } \\
\text { density }\end{array}$} & \multirow[t]{2}{*}{ Pheo. } & \multirow{2}{*}{$\begin{array}{l}\text { Salinity } \\
\text { (PSU) }\end{array}$} & \multirow{2}{*}{$\begin{array}{c}\text { Bacteria } \\
\left(10^{9}\right)\end{array}$} & \multirow{2}{*}{$\begin{array}{c}\text { Water } \\
\text { content }\end{array}$} \\
\hline & & & & & Coll carb & Bound carb & Coll prot & Bound prot & & & & & \\
\hline 14 & $8 \mathrm{~h} 40^{\prime}$ & 11.0 & 64.2 & 27.0 & 2.01 & 13.32 & 1.51 & 3.73 & 7809 & 58.7 & 37.23 & 0.784 & 51,8 \\
\hline 15 & $9 h 40^{\prime}$ & 11.5 & 66.1 & 19.1 & 4.24 & 19.45 & 0.00 & 0.00 & 9903 & 60.3 & 38.62 & 1.257 & 50,6 \\
\hline 16 & $10 \mathrm{~h} 35^{\prime}$ & 11.4 & 63.3 & 21.0 & 6.43 & 20.93 & 0.00 & 0.00 & 11431 & 62.4 & 39.18 & 0.658 & 51,4 \\
\hline 17 & $11 \mathrm{~h} 30^{\prime}$ & 11.6 & 58.7 & 16.2 & 1.34 & 10.39 & 0.25 & 0.34 & 12110 & 63.4 & 41.68 & 0.978 & 49,5 \\
\hline 18 & $12 \mathrm{hOO}^{\prime}$ & 11.3 & 57.3 & 16.6 & 1.87 & 10.82 & 0.30 & 1.00 & 13242 & 63.1 & 42.38 & 0.548 & 49,9 \\
\hline 19 & $12 \mathrm{~h} 35^{\prime}$ & 11.0 & 56.3 & 16.6 & 3.46 & 12.82 & 0.00 & 0.00 & 17146 & 63.4 & 41.54 & 0.608 & 49,1 \\
\hline 20 & $13 \mathrm{hOo}^{\prime}$ & 10.4 & 54.8 & 16.3 & 13.32 & 11.51 & 0.89 & 0.84 & 18957 & 66.4 & 45.51 & 0.369 & 47,7 \\
\hline 21 & $13 \mathrm{~h} 40^{\prime}$ & 11.8 & 48.0 & 16.3 & 11.61 & 11.39 & 1.34 & 1.28 & 20542 & 63.5 & 46.42 & 0.551 & 49,1 \\
\hline 22 & $14 \mathrm{~h} 20^{\prime}$ & 11.1 & 54.9 & 16.8 & 9.82 & 10.63 & 0.88 & 1.94 & 25408 & 61.4 & 47.60 & 0.730 & 50,4 \\
\hline 23 & $15 \mathrm{~h} 15^{\prime}$ & 11.2 & 67.5 & 17.5 & 13.89 & 9.79 & 0.80 & 1.35 & 26483 & 62.9 & 48.23 & 0.679 & 50,9 \\
\hline 24 & $15 \mathrm{~h} 55^{\prime}$ & 11.2 & 68.1 & 15.9 & 9.25 & 8.61 & 1.49 & 2.16 & 29086 & 62.0 & 48.09 & 0.659 & 48,7 \\
\hline 25 & $16 \mathrm{~h} 30^{\prime}$ & 10.9 & 68.3 & 18.0 & 13.04 & 12.86 & 1.54 & 2.13 & 29822 & 63.8 & 36.95 & 0.698 & 52,5 \\
\hline 26 & $17 \mathrm{~h} 25^{\prime}$ & 10.1 & 52.3 & 18.1 & 13.03 & 11.76 & 2.01 & 2.33 & 31180 & 64.4 & 42.80 & 0.873 & 52,6 \\
\hline $\begin{array}{c}\text { Mean } \\
\text { SE } \\
\% \text { of error }\end{array}$ & $\begin{array}{l}66.6 \\
10.0 \\
15.1\end{array}$ & $\begin{array}{l}11.1 \\
0.35 \\
3.11\end{array}$ & $\begin{array}{l}61.8 \\
4.9 \\
8.0\end{array}$ & $\begin{array}{l}17.6 \\
2.0 \\
12.71\end{array}$ & $\begin{array}{c}13.03 \\
3.56 \\
27.3\end{array}$ & $\begin{array}{c}11.76 \\
2.66 \\
22.6\end{array}$ & $\begin{array}{l}2.01 \\
0.46 \\
23.0\end{array}$ & $\begin{array}{l}2.33 \\
0.81 \\
34.7\end{array}$ & $\begin{array}{c}19471 \\
6083 \\
31.24\end{array}$ & $\begin{array}{l}62.7 \\
1.41 \\
2.25\end{array}$ & $\begin{array}{c}42.79 \\
3.02 \\
7.05\end{array}$ & $\begin{array}{l}0.723 \\
0.163 \\
22.62\end{array}$ & $\begin{array}{l}50,3 \\
1,10 \\
2,18\end{array}$ \\
\hline
\end{tabular}


2 Table 3: Multiple regression model between erodibility parameters versus physical/biological

3 factors at the sediment surface

\begin{tabular}{|c|c|c|c|}
\hline EPS & Erosion type & Multiple regression model (Explanatory variables in a decreasing order of dominance) & $\mathrm{R}^{2}$ \\
\hline$\tau_{\text {crit-chla }}$ & Fluff layer erosion & $+0.412 \times$ Pheo $-0.00007 \times$ Peringia $-0.98 \times \mathrm{D}_{\text {median }}-151.8$ & 0.75 \\
\hline$E_{\text {chla-fluff }}$ & & $-0.0352 \times$ Chla $\left(1^{\mathrm{st}} \mathrm{cm}\right)+0.33 \times \mathrm{D}_{\text {median }}-0.025 \times \mathrm{S} \% 0-0.0352$ & 0.73 \\
\hline$\tau_{\text {crit-sed }}$ & Mass erosion & $-1.78 \times$ Bound EPS Prot. +6.634 & 0.24 \\
\hline$E_{\text {chla-mass }}$ & & I & 1 \\
\hline $\mathrm{E}_{\text {sed-mass }}$ & & $+6.10 \times$ Bound EPS Carb $-11.8 \times$ Chla $\left(1^{\mathrm{st}} \mathrm{mm}\right)-6.52 \times \mathrm{S} \% 0+487$ & 0.88 \\
\hline
\end{tabular}

4

5

6

7

8

9

10

11

12

13

14

15

16

17

18

19 
Figure 1. Design of the erodimeter. Data from July 22.

A
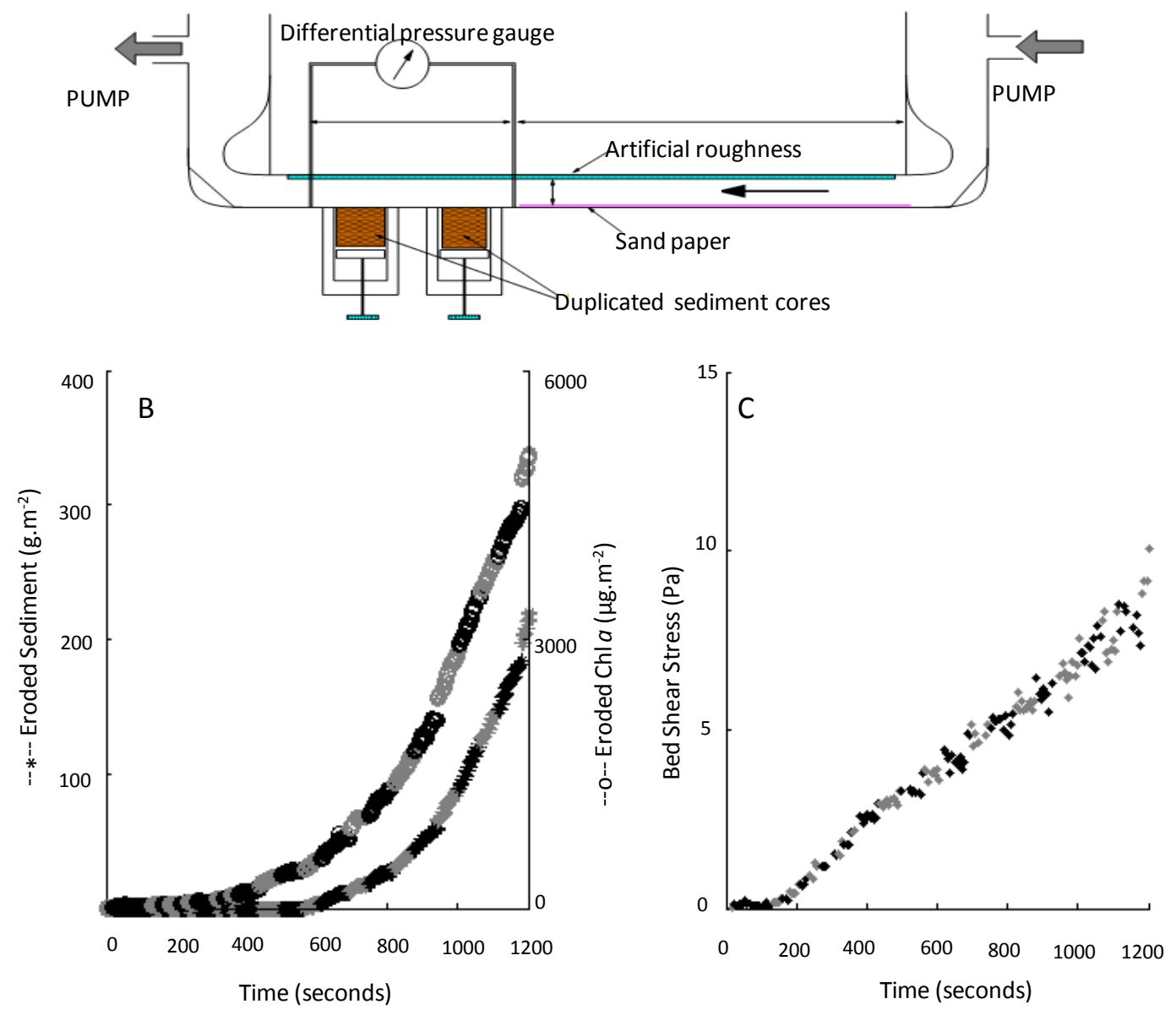
22 Figure 2: Averaged resuspended mass according to sheer velocity from July14 to 26: A) SPM

$\left.23\left(\mathrm{~g} / \mathrm{m}^{2}\right) ; \mathrm{B}\right)$ Chl- $a\left(\mu \mathrm{g} / \mathrm{m}^{2}\right)$.

24

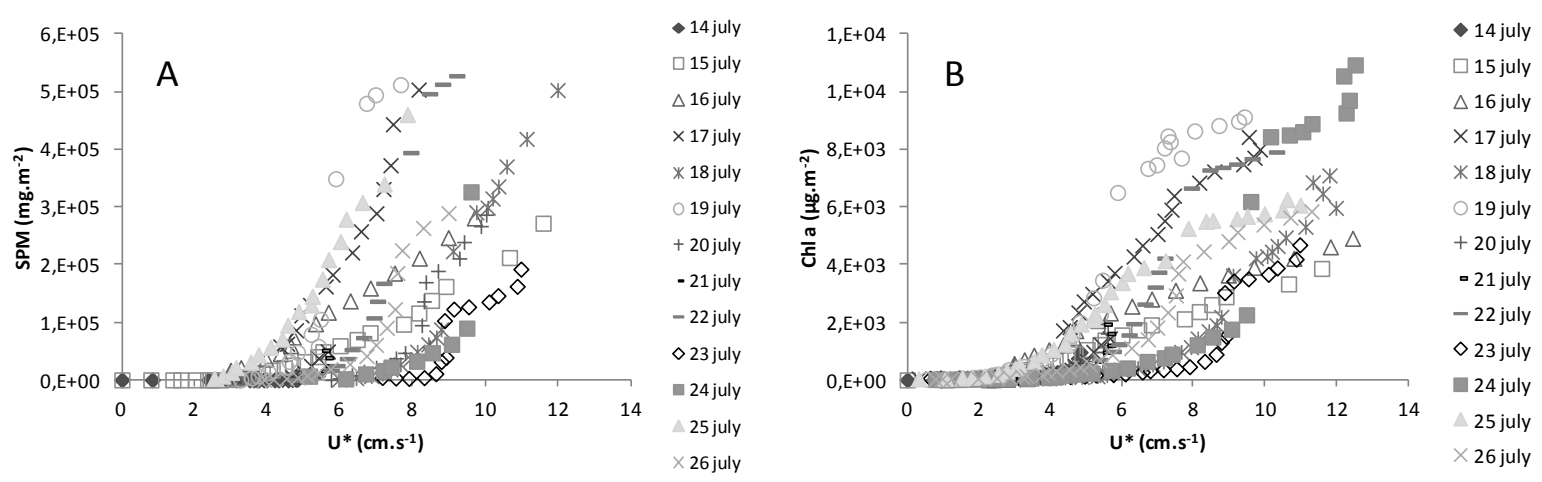


25 Figure 3: Dynamics of sediment erodibility with critical thresholds for erosion (A) and 26 erosion rates of chl- $a$ biomass in the erodimeter (B). Critical Bed Shear Stress (Pa) for mass 27 resuspension of sediment $\left(\tau_{\text {crit-sed }}\right)$ and initial resuspension of microphytobenthos $\left(\tau_{\text {crit-chla }}\right)$ are 28 compared to the maximal Bed Shear Stress $\left(\tau_{\mathrm{f}}\right)$ measured on the field using an ADV
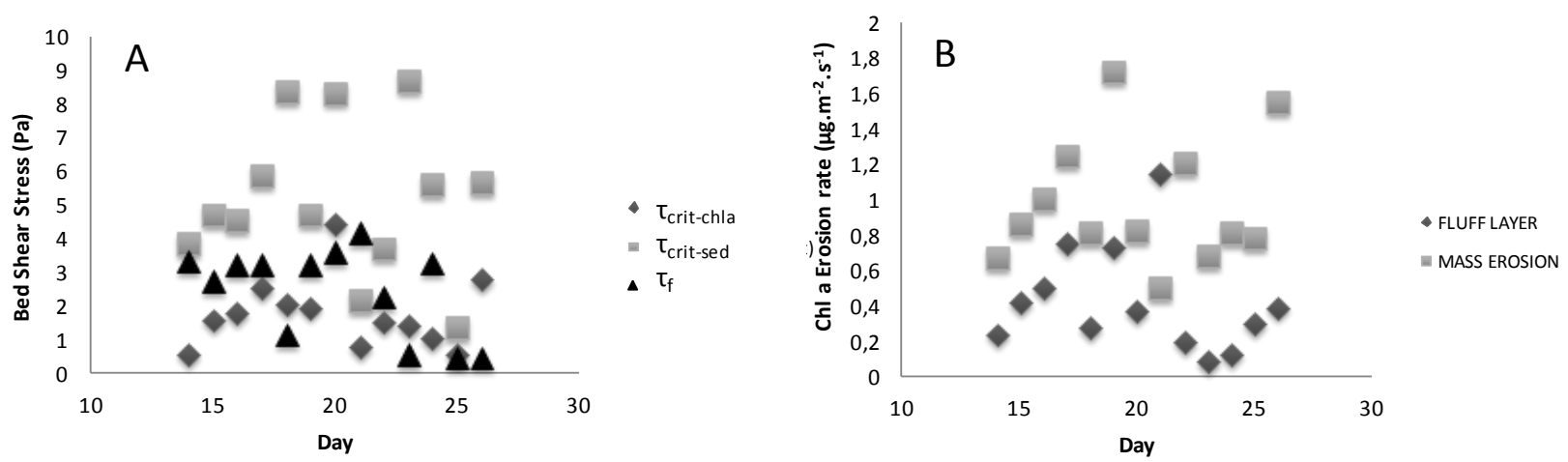
31 Figure 4: Pearson's Correlation plots between the best correlated sediment and erodibility

32 parameters (i.e. first descriptor among the set of explanatory factors in Table 3; Degree of 33 significance are given by the presence of one asterisk : $\mathrm{P}<0.05$ and $\mathrm{ns}=$ Not Significant) :

34 A) Critical threshold for chl- $a$ erosion versus pheopigment percentage $(y=0.37 . x-21.7 ; \mathrm{R}=$ 35 $\left.0.68^{*}\right)$; B) Chl- $a$ erosion rate versus chl- $a$ sediment concentration $(\mathrm{y}=-0.0275+2.07 ; \mathrm{R}=-$ $\left.0.62^{*}\right)$; C) Critical threshold for sediment erosion versus bound EPS protein content $(\mathrm{y}=-$ $\left.\left.1.78+6.63 ; \mathrm{R}=-0.49^{\mathrm{ns}} ; \mathrm{P}=0.09\right) ; \mathrm{D}\right)$ Sediment erosion rate versus bound EPS
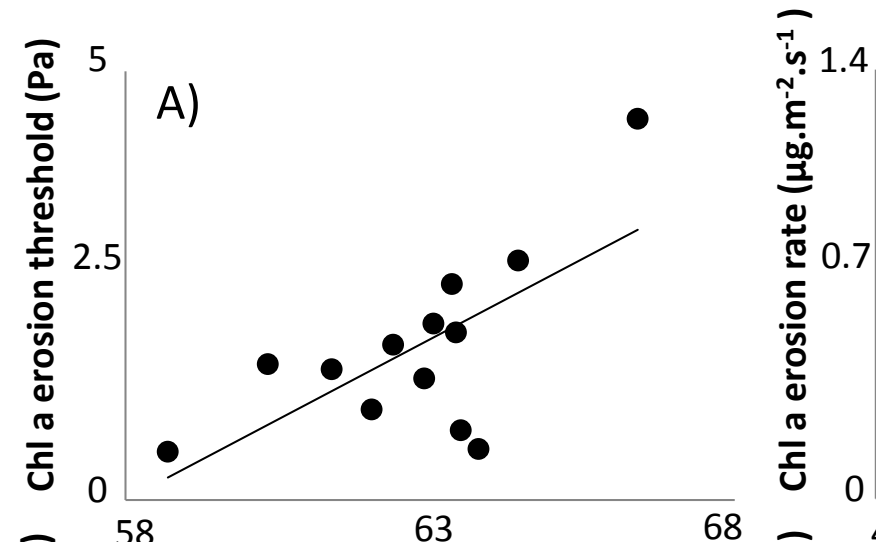

B)
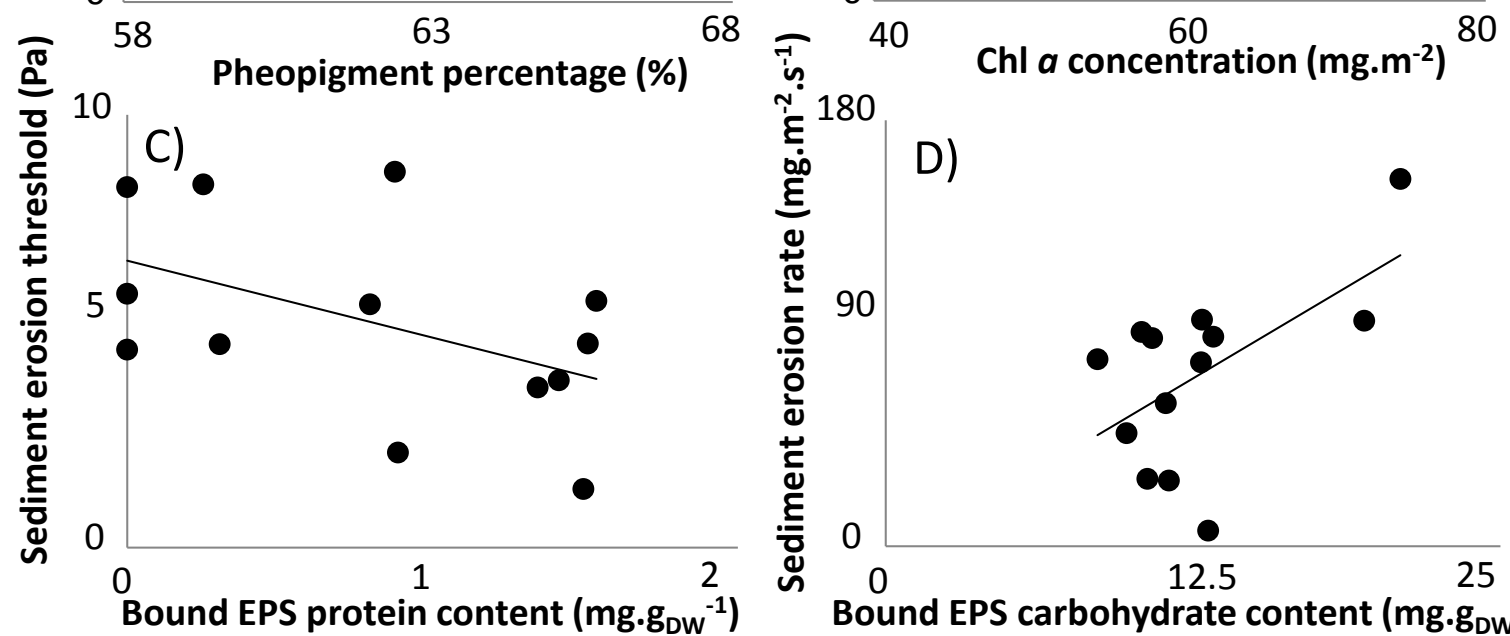
40 Figure 5: Exportation of chl- $a$ (A) and sediment (B) from the mudflat to the water column

41 during the 13 days in summer.

\section{Sediment $\diamond \mathrm{Chla}$}

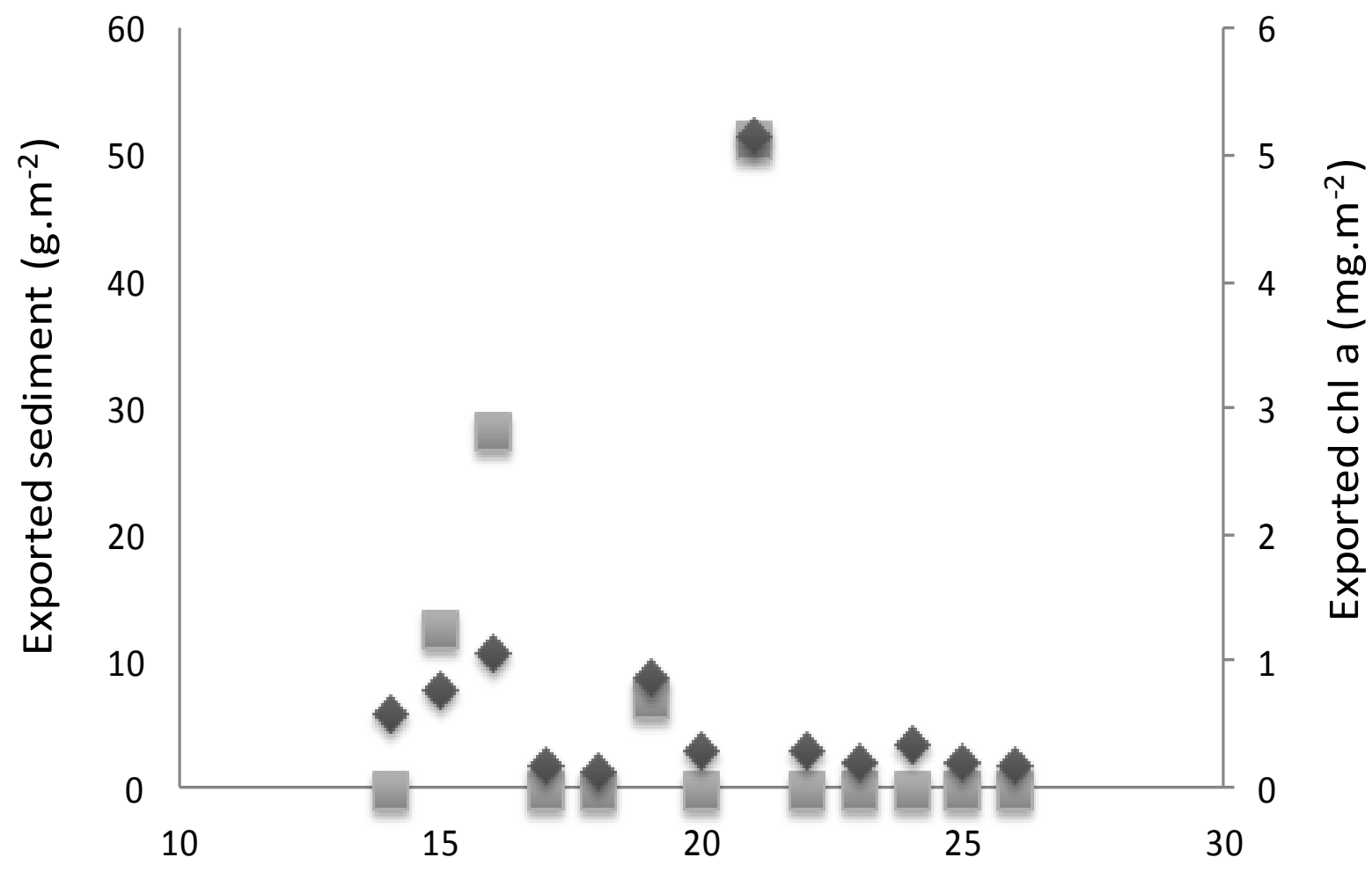

